\title{
"A Case Study on Optimum Days Rquired for Crushing Of Boulder Slag by Using Least Square Method"
}

\author{
Md. Tanweer Ahmad ${ }^{1}$, Anil P. Goyal ${ }^{2}$ \\ ${ }^{I}$ Mechanical, ITM-University, Gwalior, India \\ ${ }^{2}$ Mechanical, ITM-University, Gwalior, India
}

\begin{abstract}
Vehicle utilization at the organizational level has been defined as a "Strategy for the acquisition, utilization, improvement and retention of an enterprise's functions".

The primary objective of this study is to identify the existing system of crushing and number of days required for crushing of boulder slag for future year by applying least square method of linear regression.

In-Plant logistics is one of the most important sections within enterprises, especially in the large manufacturing companies. It manages, arranges, plans and delivers the finished products as well as waste product.

As we know that the slag formation is the waste material of steel industries through blast furnace in which the main product is hot metal. This slag are of two types:- one is granulated slag and other is boulder slag, the granulated slag is directly sell to the cement industry and boulder slag which becomes lump with moisture is crushed then sell to the cement industry. Our attention is on boulder slag which is crushed through various machining process.
\end{abstract}

Keywords; bottleneck identification, data analysis, internal logistics, least square method, turn-around time.

\section{Introduction}

Granulated slag handling has potential to become the next governing element of corporate strategy to create value for customers, generate cost savings, enforce discipline in marketing efforts and extend the flexibility of production.

Expressed in simple language, materials handling is loading, moving and unloading of materials. To do it safely and economically, different types of tackles, gadgets and equipment are used, when the materials handling is referred to as mechanical handling of materials. Since primitive men discovers the following theory.

$>\quad$ Based on the need to be of optimum design and application specific to different type of industries, materials handling can be as diverse as industries themselves. As a consequence, unfortunately, there is no universally accepted definition of materials handling..Some of the other definitions are:-Materials handling is the movement and storage of materials at the lowest possible cost through the use of proper methods and equipment[1].

$>\quad$ Materials handling is the moving of materials or product by any means, including storage, and all movements except processing operations and inspection [2].

$>\quad$ Materials handling is the art and science of conveying.

There are other definitions also, but above few jointly bring out the salient features of materials handling. It is referred to as an art and science because to most of the materials handling problem no unique solution exists and more than one solution may be prescribed. Lot of subjective considerations of the materials handling engineer go into it. At the same time many scientific factors are also considered to arrive at the solution. In one of the definitions, all the functions of materials handling have been referred to which are crushing, conveying, elevating, positioning, transporting, packaging and storing.

Modern logistics is defined as: the process of planning, implementing, and controlling the efficient, effective flow and storage of goods, services, and related information from point of origin to the point of consumption for the purpose of conforming to customer requirement (Johnson, Wood, Wardlow \& Murphy, 1998, 5) Logistics/ supply-chain management is the synchronized movement of inputs and outputs in the production and delivery of goods and services to the customer.

In this integrative approach, a cross functional senior management group coordinates physical and informational resources to optimize efficiency and effectiveness [3].

This paper analyses the optimum days required for crushing the boulder slag in movement of crusher inside the Railway siding yard. The reasons for high turn-around time are identified using data analysis and several other management science tools. Based on several research studies, it has been identified that major factors affecting the detention time of heavy vehicle in a the heap of boulder slag are poor layout of the plant, weigh practices, and several other operational issues. 
Some of these materials directly goes to cement plant and remaining material which gets solidify that is called boulder slag has to be heaped at siding railway yard. The heaps are then divided into two to three groups and each group is placed on same or different.

There are four types of vehicle is employed for the crushing purposes and each vehicle is employed for different working categories. The existing system consists of four different processes such as "loading, heaping , spreading, crushing."

It has been shown below that tells us which type of heavy vehicle did which type of job.

\begin{tabular}{|c|c|c|}
\hline Sr.no. & Equipment & Activity \\
\hline 1 & Poclain & $\begin{array}{c}\text { For breaking of the heap of } \\
\text { boulder slag }\end{array}$ \\
\hline 2 & Compactor & $\begin{array}{c}\text { For crushing of boulder lump of } \\
\text { slag }\end{array}$ \\
\hline 3 & Payloader & $\begin{array}{c}\text { For spreading of boulder lump for } \\
\text { crushing \& making heap of } \\
\text { crushed slag }\end{array}$ \\
\hline 4 & Hywa & $\begin{array}{c}\text { For shifting the crushed slag near } \\
\text { the railway loading point }\end{array}$ \\
\hline
\end{tabular}

\section{Modelling The Materials Handling System Selection Problem}

The proposed model is designed to consider minimization of total cost and aisle space requirements as compared to the previous models [8,9] which minimize only the total cost of operation and investment. Furthermore, the proposed model, allows other design considerations to be treated as parameters, determines the optimum days required for crushing of boulder slag with existing equipment and selects a candidate set of equipment through a knowledge base. All of these are new additions to the previous concepts in analytical procedures.

\subsection{Steps for Method used for data collection:[4]}

1. Select the Section to be studied.

2. Obtain all detail of heavy vehicle deployed and past data from log sheet.

3. Validation of past data by field observation using work sampling.

4. Calculation of Standard time with the help work sampling for different type of activities.

5. Add the suitable allowances to compensate for fatigue, personal needs, contingencies, etc. Standard Time = Normal Time* Allowance Factor

6. Calculation of required man hour for different type of maintenance work.

7. Consideration of Supervision work and Management hierarchy as per company policy.

Proposal for Optimum vehicle deployment.

\section{Genesis Of Problem}

Presently 1-poclain, 1-payloader, 1-hywa, 1-compactor are present in the Railway siding yard for 12 months for crushing of boulder slag which is generated by BF-I \& II department.

The profit analysis are as follows:-

\begin{tabular}{|c|c|c|c|}
\hline \multicolumn{4}{|c|}{ Profit Analysis (Monthly) } \\
\hline Particulars & RS/Ton & Quantity(Month) & Total Cost \\
\hline $\begin{array}{l}\text { Cost of } \\
\text { Boulder Slag }\end{array}$ & 450 & 15000 & 675000 \\
\hline $\begin{array}{l}\text { Total } \\
\text { expenses to } \\
\text { crush the } \\
\text { Boulder Slag } \\
\end{array}$ & 46 & 15000 & 690000 \\
\hline $\begin{array}{l}\text { Cost of } \\
\text { crushed Slag } \\
\text { in the Market }\end{array}$ & 925 & 15000 & 13875000 \\
\hline $\begin{array}{l}\text { Positive Varial } \\
\text { Method And E }\end{array}$ & $\begin{array}{l}\text { Arrive } \\
\text { ipment }\end{array}$ & By Using Existing & 6435000 \\
\hline
\end{tabular}

In Railway siding yard there is approximately 25000 MT per month granulated slag of which about 15000 MT is hard and lumpy which requires to be crushed before dispatch.

The above profit analysis suggests that the crushing of boulder slag is beneficial and after crushing it should be sold in the market. 


\section{Observation}

To assess the present utilization of machine deployed in Railway siding yard, we have conducted Time study of the entire workshop on $7^{\text {th }}$ January'2013 (for 12 Hrs.), $23^{\text {rd }}$ January'2013(for 12 Hrs.) and $5^{\text {th }}$ February'2013 (for 12 Hrs.). The summary sheet of slag crushing at railway siding yard are as follows:-

Summary Sheet Of Slag Crushing :-

\begin{tabular}{|c|c|c|c|c|}
\hline $\begin{array}{l}\text { Sr. } \\
\text { No. }\end{array}$ & Activity & $\begin{array}{c}\text { Duration } \\
\text { (In Min) }\end{array}$ & $\begin{array}{c}\text { Quantity of } \\
\text { Material } \\
\text { (In Ton) }\end{array}$ & Remarks \\
\hline \multicolumn{5}{|c|}{ Working:- } \\
\hline 1 & $\begin{array}{l}1^{\text {st }} \text { Cycle } \\
\text { Operation }\end{array}$ & 105 & 110 & $\begin{array}{l}\text { 1payloader } \\
\text { 1compactor } \\
\text { were used }\end{array}$ \\
\hline 2 & $\begin{array}{l}2^{\text {nd }} \text { Cycle } \\
\text { Operation }\end{array}$ & 89 & 120 & $\begin{array}{l}\text { 2payloader } \\
\text { 1compactor } \\
\text { were used }\end{array}$ \\
\hline 3 & $\begin{array}{l}3^{\text {rd }} \text { Cycle } \\
\text { Operation }\end{array}$ & 98 & 120 & $\begin{array}{l}\text { 2payloader } \\
\text { 1compactor } \\
\text { were used }\end{array}$ \\
\hline 4 & $\begin{array}{l}4^{\text {th }} \text { Cycle } \\
\text { Operation }\end{array}$ & 117 & 110 & $\begin{array}{l}\text { 1payloader } \\
\text { 1compactor } \\
\text { were used }\end{array}$ \\
\hline 5 & $\begin{array}{l}5^{\text {th }} \text { Cycle } \\
\text { Operation }\end{array}$ & 118 & 110 & $\begin{array}{c}\text { 1payloader } \\
\text { 1compactor } \\
\text { were used }\end{array}$ \\
\hline \multicolumn{2}{|r|}{ Total-1 } & 527 & 570 & \\
\hline \multicolumn{2}{|c|}{$\begin{array}{c}\text { Average Cycle time } \\
\text { without delays }\end{array}$} & 113 & 110 & \\
\hline \multicolumn{5}{|c|}{ ii) Idle } \\
\hline 1 & No Manpower & 58 & & $\begin{array}{l}\text { At the time of } \\
\text { shift change }\end{array}$ \\
\hline 2 & $\begin{array}{c}\text { Preventive } \\
\text { Maintenance } \\
\text { \&Fuel Filling } \\
\end{array}$ & 57 & & $\begin{array}{l}\text { Greasing, Oiling } \\
\text { \& Checking }\end{array}$ \\
\hline 3 & Lunch & 78 & & \\
\hline \multicolumn{2}{|r|}{ Total-II } & 193 & & \\
\hline
\end{tabular}

$1^{\text {st }}$ cycle operation there is $110 \mathrm{MT}$ was crushed in 110 minutes by 1-payloader \& 1-compactor was deployed. $2^{\text {nd }}$ cycle operation there is 120 MT was crushed in 89 minutes by 2-payloader \& 1 -compactor was deployed. $3^{\text {rd }}$ cycle operation there is 120 MT was crushed in 98 minutes by 2 -payloader \& 1-compactor was deployed. $4^{\text {th }}$ cycle operation there is 110 MT was crushed in 117 minutes by 1-payloader \& 1 -compactor was deployed. $5^{\text {th }}$ cycle operation there is 110 MT was crushed in 118 minutes by 1-payloader \& 1-compactor was deployed.

\section{Assessment Of Requirement :-}

\begin{tabular}{|l|l|l|}
\hline Total Available Time per Day & 24 & Hrs \\
\hline Considering Standard Time per Day & 20 & Tones \\
\hline Average Slag Crushed per Day & 110 & Tones \\
\hline Material Left in the Yard For Crushing & 15000 & Tones \\
\hline Average Cycle Time & 113 & Mins per Day \\
\hline Approx. Time Required to Crush the Material & 13 & Days per Month \\
\hline Approx. Time Required to Crush the Material & 154 & Days per Year \\
\hline
\end{tabular}

\section{Recommendation}

The above model suggests that the 13 days per month and 154 days per year required for crushing the boulder slag with recommended vehicle deployment for the period of 2012-13.

We also observed that the recommended vehicle is 1-poclain, 1-payloader, 1-compacter, 1-Hywa would be same and we only focus on reducing the days required to crush the boulder slag for next period 2013-14.For this we will apply the past data of generation of granulated slag of which the quantity becomes boulder slag. I have past 5 years data of generation of granulated slag by the both the department BF-I \& II.

Actual Days Required For Crushing In Last Four Years, calculated as per above calculation on the basis of quantity produced (slag formation) per month. 


\begin{tabular}{|c|c|c|}
\hline Period & $\begin{array}{c}\text { Quantity to } \\
\text { Produced Per } \\
\text { Month }\end{array}$ & Time Required to Crush in Days \\
\hline $2009-10$ & 21000 & 216 \\
\hline $2010-11$ & 18000 & 185 \\
\hline $2011-12$ & 20000 & 205 \\
\hline $2012-13$ & 15000 & 154 \\
\hline
\end{tabular}

The simplest method to estimate the trend in a time series is to treat the time period as independent variables and actual demand as a dependent variable. Using the standard method of least squares, it is possible to estimate the trend component[6].

Consider the following notations pertaining to a time series:-

$\mathrm{X}_{\mathrm{i}}=$ Time period

$\mathrm{Y}_{\mathrm{i}}=$ No. days required for crushing during period ' $\mathrm{I}$ '.

$\mathrm{a}=$ Intercept (at period ' 0 ')

$\mathrm{b}=$ Slope of the line.

Then simple linear regression of the form $Y=a+b X$ could be constructed to predict the number of days required for crushing ' $\mathrm{Y}$ ' for any value of ' $\mathrm{X}$ '.

The co-efficient of the regression equation could be computed using the method of least square.

$b=\frac{\sum X_{i} Y_{i}-n \bar{X} \bar{Y}}{\sum X_{i}^{2}-n \bar{X}^{2}}$

$\boldsymbol{a}=\overline{\boldsymbol{Y}}-\boldsymbol{b} \bar{X}$

Where, ' $\mathrm{n}$ ' is the number of periods

and $\bar{X}=\frac{\sum X_{i}}{n}, Y=\frac{\sum Y_{i}}{n}$

\begin{tabular}{|l|l|l|l|l|}
\hline Period & $\mathbf{X}$ & $\mathbf{Y}$ & $\mathbf{X} \times \mathbf{X}$ & $\mathbf{X} \times \mathbf{Y}$ \\
\hline $2009-10$ & 1 & 216 & 216 & 1 \\
\hline $2010-11$ & 2 & 185 & 370 & 4 \\
\hline $2011-12$ & 3 & 205 & 615 & 9 \\
\hline $2012-13$ & 4 & 154 & 616 & 16 \\
\hline Sum & $\mathbf{1 0}$ & $\mathbf{7 6 0}$ & $\mathbf{1 8 1 7}$ & $\mathbf{3 0}$ \\
\hline
\end{tabular}

From the above table shown we can find that:-

$\bar{X}=\frac{10}{4}=2.5$ and $\bar{Y}=\frac{760}{4}=190$

We can compute ' $b$ ' from equation (1):-

$\mathrm{b}=-16.6 \quad \& \quad \mathrm{a}=231.5$

The linear trend for the time series is given by:-

$Y=231.5-16.6 X$

Now, the forecasts for the $5^{\text {th }}$ year can be found out by above regression model. By putting $X=5$ then $Y=148.5$. It means we can say that for the period of 2013-14, for crushing of boulder slag, 149 days are required with recommended heavy vehicle.

We can also compute the granulated slag generation during the period of 2013-14 with the help of calculated no. of days. The approximately slag generation would be 14,513 MT . 


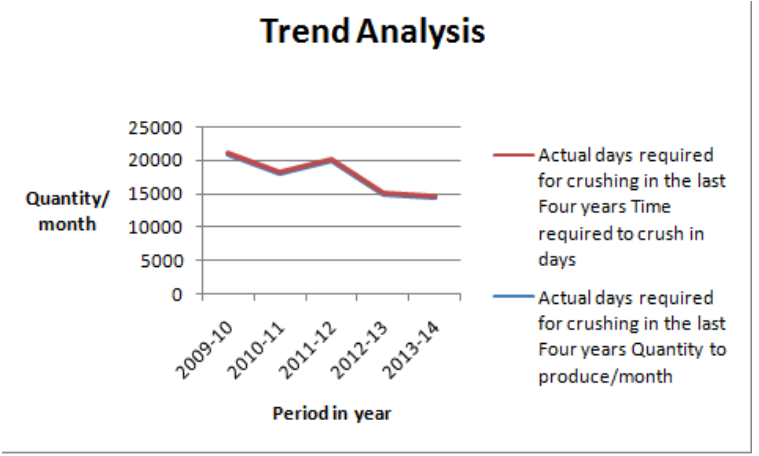

The graph has been shown above is trend of slag generation or no. days required for crushing the boulder slag versus period in year. As we see with the help of graph that as time increases there is decreasing of generation of granulated slag as well as boulder slag.

The department has indicated that due to increasing of advanced technology, the regular formation of hot metal enhancing monotonously, that is why the formation of slag decreasing time to time. Before outsourcing of the job, we are of the view that proper Buy or Make study should be carried out. Decision of Buy or Make depends on whether the machinery that is freed would remain idle or can be utilized profitably.

The lead time for the outsourced job is high as compared to the jobs processed in Railway siding yard.

There will be definite savings in transportation charges being levied on outsourced jobs.

Finally, there is huge saving in machining charges, as the jobs processed within the Railway siding yard as per our study conducted.

The Railway siding yard of JSPL, Raigarh should adopt this kind of Make or Buy Decision practices in future to decide whether it is economical to make or buy before outsourcing the jobs for crushing.

\section{Conclusion}

As we have observed in our data analysis, the vehicles(1-poclain,2-payloader,1-hywa,1-compacter) of Railway siding yard are being deployed for crushing of boulder slag for 1 year. As per our study conducted, it is revealed that the same vehicles would be deployed for 150 days instead of 1 year with same procedure of crushing of boulder slag. This will influence in the cost of crushing and return on investment will also improve.

\section{References}

[1] Barnes, R.L.,(1980) "Motion and time study", Design and Measurement of work, $7^{\text {th }}$ Edn., John Wiley and Sons, New York.

[2] Barnes, Ralph M. (1957). "Work sampling”, $2^{\text {nd }}$ Edn., New York and London, John Wiley and Sons, New York.

[3] Bechtold et al., (1991) "The labour tour scheduling methods as per labour demand requirements distributions", Journal of production and operation 12, 104-129

[4] International Labour Office Geneva. (1957). "Inroduction to Work Study", $3{ }^{\text {rd }}$ Edn, Universal Book Corporation, Mumbai, 9-20.

[6] A book of operation Management by B. Mahadevan. 